Case Report

\title{
Hypoxemic Bronchiolitis Related to Major Histocompatibility Class II Deficiency
}

\author{
S. Hammami, H. Besbès, S. Hadded, K. Lajmi, L. Ghédira, \\ Ch. B. Meriem, and M. N. Guediche
}

Paediatric Department, Fattouma Bourguiba Hospital and University of Monastir, Faculty of Medicine, 5000 Monastir, Tunisia

Correspondence should be addressed to S. Hammami; hamami_sabeur@yahoo.fr

Received 28 May 2013; Accepted 14 July 2013

Academic Editor: Gerald S. Supinski

Copyright (C) 2013 S. Hammami et al. This is an open access article distributed under the Creative Commons Attribution License, which permits unrestricted use, distribution, and reproduction in any medium, provided the original work is properly cited.

\begin{abstract}
Major histocompatibility complex class II expression deficiency is an autosomal recessive primary combined immunodeficiency. The prevalence of this deficiency is the highest in Mediterranean areas, especially North Africa. Early diagnosis is essential due to high mortality in the first 2 years of life. Prognosis is very poor when bone marrow transplantation cannot be performed. We report the case of an infant with major histocompatibility complex class II expression deficiency revealed by hypoxemic bronchiolitis due to Pneumocystis jiroveci.
\end{abstract}

\section{Introduction}

Major histocompatibility complex (MHC) class II deficiency is a rare inherited primary combined immunodeficiency syndrome characterized by defective expression of HLA class II antigens [1]. The majority of cases reported are from North Africa. Early diagnosis is essential due to high mortality in the first 2 years of life because of high susceptibility to a broad range of viral, bacterial, fungal, and protozoan infections [2, 3]. We report a new case of this disease revealed by hypoxemic bronchiolitis.

\section{Case Report}

A 6-month-old infant, of healthy consanguineous parents, presented to our pediatric unit on the January 2, 2012, for fever with cough. The infant had one month's history of polypnoea and cough. He was born at term, weighing $3500 \mathrm{~g}$, with Apgar scores of 9 and 10 at 1 and 5 minutes, respectively. He received breast-feeding for 4 months. Infant had normal psychomotor development. He weighed $4500 \mathrm{~g}$, his height was $60 \mathrm{~cm}$, and temperature was at $38.5^{\circ} \mathrm{C}$. Physical examination noted polypnoea, tachycardia without signs of heart failure, and perioral cyanosis with oxygen saturation at $78 \%$.
Complete blood cell showed moderate hypochromic microcytic aregenerative anemia and leukocytosis. Iron investigation showed low ferritinemia, compatible with iron deficiency. Inflammatory markers were moderately increased. A chest X-ray revealed bilateral alveolointerstitial infiltrate (Figure 1). Viral serology particularly human immunodeficiency virus was negative. Test for syncytial respiratory virus was negative. Laboratory tests, including renal function, serum electrolytes, and liver enzymes were normal. Blood culture was also negative. Chest computed tomography noted bilateral interstitial infiltrate. Infant received broad-spectrum antibiotic and oxygen. Initial clinical course was unfavorable with persistence of oxygen dependence. Pneumocystis jiroveci pneumonitis was evoked. Infant received trimethoprim and sulfamethoxazole (TMP/SMX) at $100 \mathrm{mg} /$ weight/day. Evolution was favorable. Control chest X-ray was normal, and infant was weaned of oxygen (Figure 2). Microbiologic tests revealed an infection with Pneumocystis jiroveci. An immunodeficiency disease was suspected based on lingering symptoms associated with poor weight gain. Immunologic investigations allowed us to make the diagnosis of MHC class II deficiency. Infant received antibiotic prophylaxis and monthly immunoglobulin treatment. Unfortunately, infant did not have an HLA-identical donor. Evolution was characterized by appearance of other recurrent infections (respiratory and 


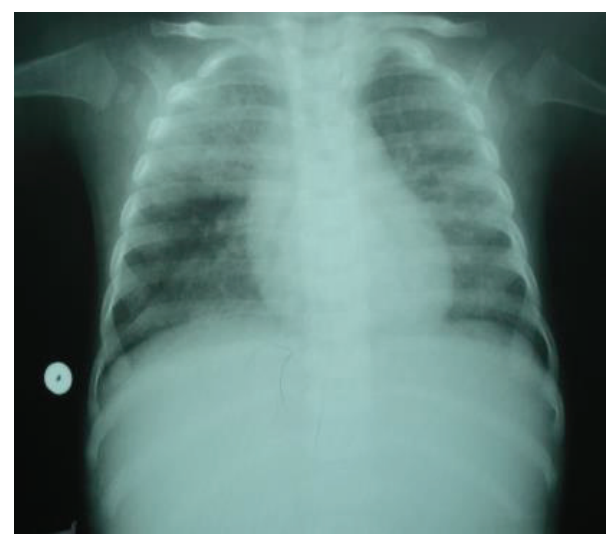

FIGURE 1: Initial chest X-ray: bilateral alveolointerstitial infiltrate.



FIgURE 2: Control chest X-ray: normal.

gastrointestinal tracts). Infant died at age of 18 months from severe denutrition and septicemia.

\section{Discussion}

Major histocompatibility complex class II (MHC-II) expression deficiency is a rare combined immunodeficiency leading to the impairment of the cellular and humoral immune responses [4]. It is an autosomal recessive disease caused by the defective expression of human leucocyte antigen (HLA) class II molecules due to mutated transacting proteins. MHC locus itself is not affected. Four genes have been identified to encode regulatory factors controlling transcription of MHC class II genes: CIITA, RFXANK, RFX5, and RFXAP. The mutations in the RFXANK gene are the most frequent and account for more than two-thirds of all reported cases [5]. In classical presentation, $\mathrm{T}$ and $\mathrm{B}$ cells are within the normal range, lymphopenia is moderate, and the lymphocyte proliferation in response to stimulation with mitogens is normal. The patient's T cells responded normally to alloantigenic stimulation and also had the capacity to develop antigen-specific cytotoxic functions. However, the $\mathrm{T}$ cells were completely naive to soluble protein antigens. The lack of MHC class II expression results in a severe defect in both humoral and cellular immune responses to foreign antigens. Patients have generally severe CD4 T-cell lymphopenia, and hypogammaglobulinemia and lack Ag-specific responses resulting in chronic diarrhea, recurrent viral, parasitic and bacterial infections, and failure to thrive [6]. Viral infections such as cytomegalovirus, enterovirus, adenovirus, and herpes simplex virus were the most common pathogens and the predominant cause of death [7]. Usually, first clinical signs of infections begin in the first year of life. Our patient developed pulmonary infection at the age of six months. Around this age, Pneumocystis jiroveci infection is indeed a classical mode of revelation of congenital severe cellular immune deficiency. Patients suffering from MHC-II expression deficiency died at a mean age of 4 years, often of bacterial or viral infections and severe denutrition [8]. Our patient died at age of 18 months of severe denutrition and gastrointestinal infection. However, MHC-II expression deficiency is quite common in North Africa [9-11]. A majority of affected patients belong to consanguineous families particularly from the Maghreb. Careful clinical and biological investigations should allow the discrimination of MHC class II deficiency from other diseases presenting with the same presentation at this age, such as severe combined immune deficiency and HIV infection. At present the only curative therapy is allogenic hematopoietic stem cell transplantation $[4,12]$. Prognosis is very poor when bone marrow transplantation cannot be performed. Despite this intensive care, overall cure rate is lower than that in other immunodeficiencies. This reduced survival is well correlated with an increased incidence of acute graft-versus-host disease and preexisting viral infections. Particularly, transplantation of cord blood stem cells may be an effective source of hematopoietic stem cells for patients with immunodeficiency disorders including diseases with a high rate of graft failure $[13,14]$.

\section{Conclusion}

Report of this new case of major histocompatibility complex class II expression deficiency confirms the frequency of this disease among the North African population. In Maghrebian settings, pediatricians should definitely consider this diagnosis in the presence of an early onset of severe and recurrent infections of the respiratory and intestinal tracts, with a failure to thrive.

\section{References}

[1] J. Villard, K. Masternak, B. Lisowska-Grospierre, A. Fischer, and W. Reith, "MHC class II deficiency: a disease of gene regulation," Medicine, vol. 80, no. 6, pp. 405-418, 2001.

[2] S. Nonoyama, A. Etzioni, H. Toru et al., "Diminished expression of CD40 ligand may contribute to the defective humoral immunity in patients with MHC class II deficiency," European Journal of Immunology, vol. 28, no. 2, pp. 589-598, 1998.

[3] M. A. Saleem, P. D. Arkwright, E. G. Davies, A. J. Cant, and P. A. Veys, "Clinical course of patients with major histocompatibility complex class II deficiency," Archives of Disease in Childhood, vol. 83, no. 4, pp. 356-359, 2000.

[4] C. Klein, M. Cavazzana-Calvo, F. Le Deist et al., "Bone marrow transplantation in major histocompatibility complex class II 
deficiency: a single-center study of 19 patients," Blood, vol. 85, no. 2, pp. 580-587, 1995.

[5] M. Siepermann, S. Gudowius, K. Beltz et al., "MHC class II deficiency cured by unrelated mismatched umbilical cord blood transplantation: case report and review of 68 cases in the literature," Pediatric Transplantation, vol. 15, no. 4, pp. E80-E86, 2011.

[6] J. W. Mannhalter, H. M. Wolf, H. Gadner, M. Potschka, and M. M. Eibl, "Cell-mediated immune functions in a patient with MHC class II deficiency," Immunological Investigations, vol. 20, no. 2, pp. 151-167, 1991.

[7] C. Klein, B. Lisowska-Grospierre, F. LeDeist, A. Fischer, and C. Griscelli, "Major histocompatibility complex class II deficiency: clinical manifestations, immunologic features, and outcome," Journal of Pediatrics, vol. 123, no. 6, pp. 921-928, 1993.

[8] C. Picard and A. Fischer, "Hematopoietic stem cell transplantation and other management strategies for MHC class II deficiency," Immunology and Allergy Clinics of North America, vol. 30, no. 2, pp. 173-178, 2010.

[9] M. Bejaoui, M. R. Barbouche, F. Mellouli et al., "Primary immunologic deficiency by deficiency of HLA class II antigens: nine new Tunisian cases," Archives of Pediatrics, vol. 5, no. 10, pp. 1089-1093, 1998.

[10] H. Naamane, O. El Maataoui, F. Ailal et al., "The 752delG26 mutation in the RFXANK gene associated with major histocompatibility complex class II deficiency: evidence for a founder effect in the Moroccan population," European Journal of Pediatrics, vol. 169, no. 9, pp. 1069-1074, 2010.

[11] I. Ben-Mustapha, K. Ben-Farhat, N. Guirat-Dhouib et al., "Clinical, immunological and genetic findings of a large tunisian series of major histocompatibility complex class II deficiency patients," Journal of Clinical Immunology, vol. 33, no. 4, pp. 865870, 2013.

[12] H. Al-Mousa, Z. Al-Shammari, A. Al-Ghonaium et al., "Allogeneic stem cell transplantation using myeloablative and reduced-intensity conditioning in patients with major histocompatibility complex class II deficiency," Biology of Blood and Marrow Transplantation, vol. 16, no. 6, pp. 818-823, 2010.

[13] M. Bonduel, A. Del Pozo, M. Zelazko et al., "Successful related umbilical cord blood transplantation for graft failure following T cell-depleted non-identical bone marrow transplantation in a child with major histocompatibility complex class II deficiency," Bone Marrow Transplantation, vol. 24, no. 4, pp. 437-440, 1999.

[14] R. Renella, C. Picard, B. Neven et al., "Human leucocyte antigen-identical haematopoietic stem cell transplantation in major histocompatiblity complex class II immunodeficiency: reduced survival correlates with an increased incidence of acute graft-versus-host disease and pre-existing viral infections," British Journal of Haematology, vol. 134, no. 5, pp. 510-516, 2006. 


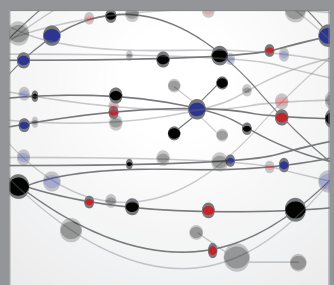

The Scientific World Journal
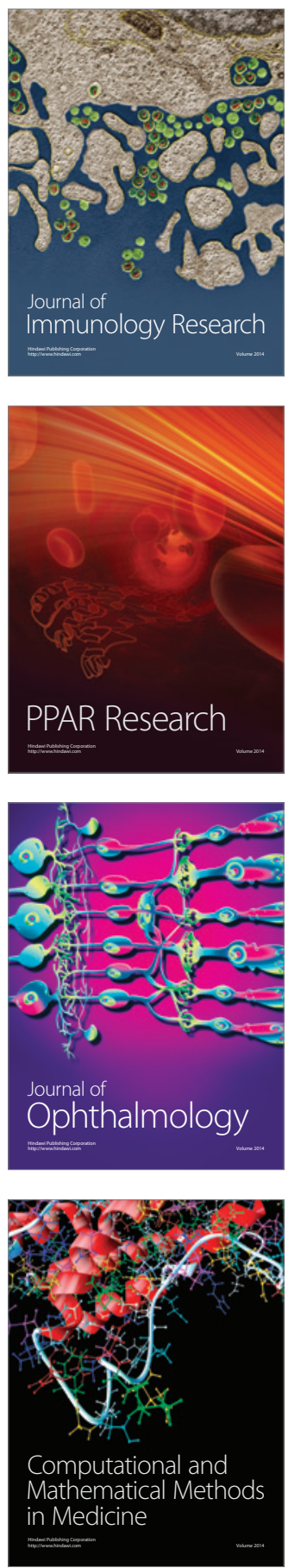

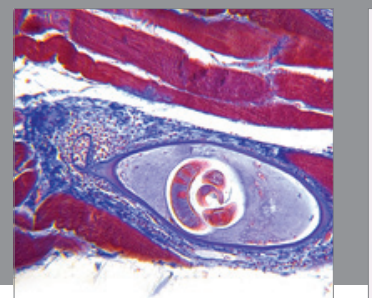

Gastroenterology

Research and Practice
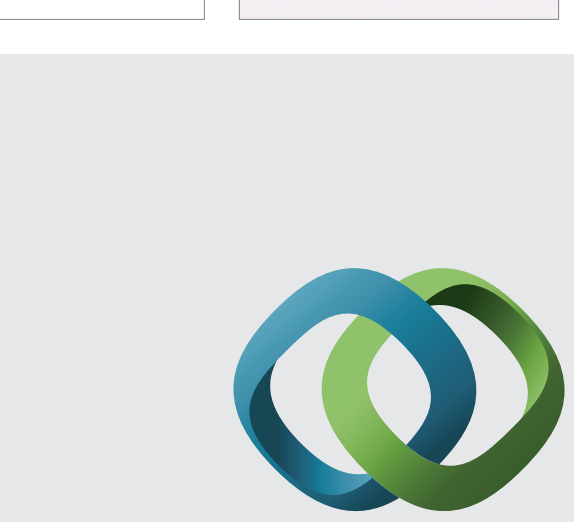

\section{Hindawi}

Submit your manuscripts at

http://www.hindawi.com
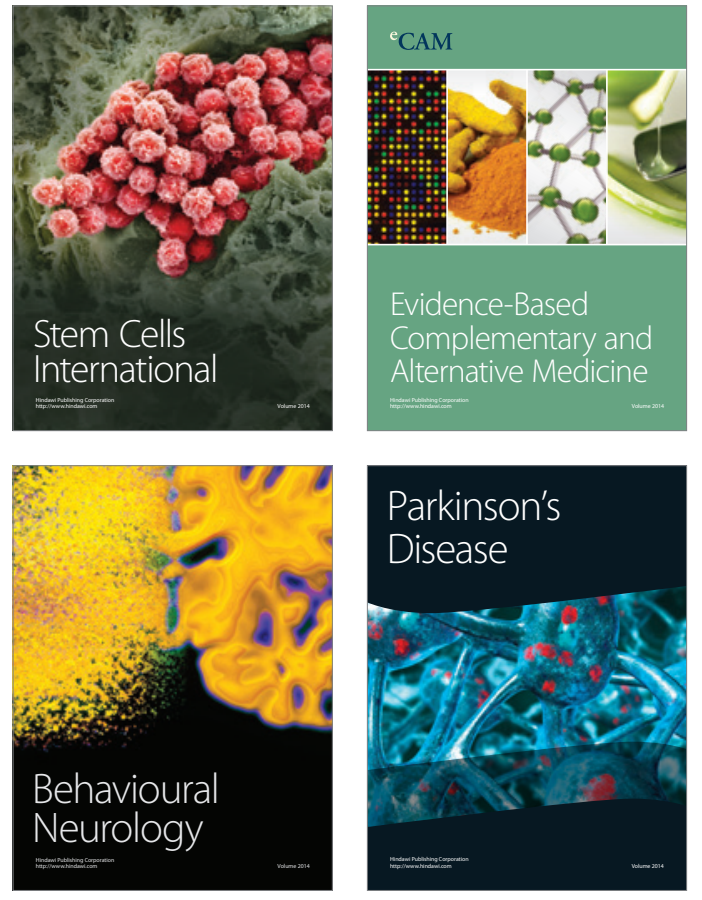
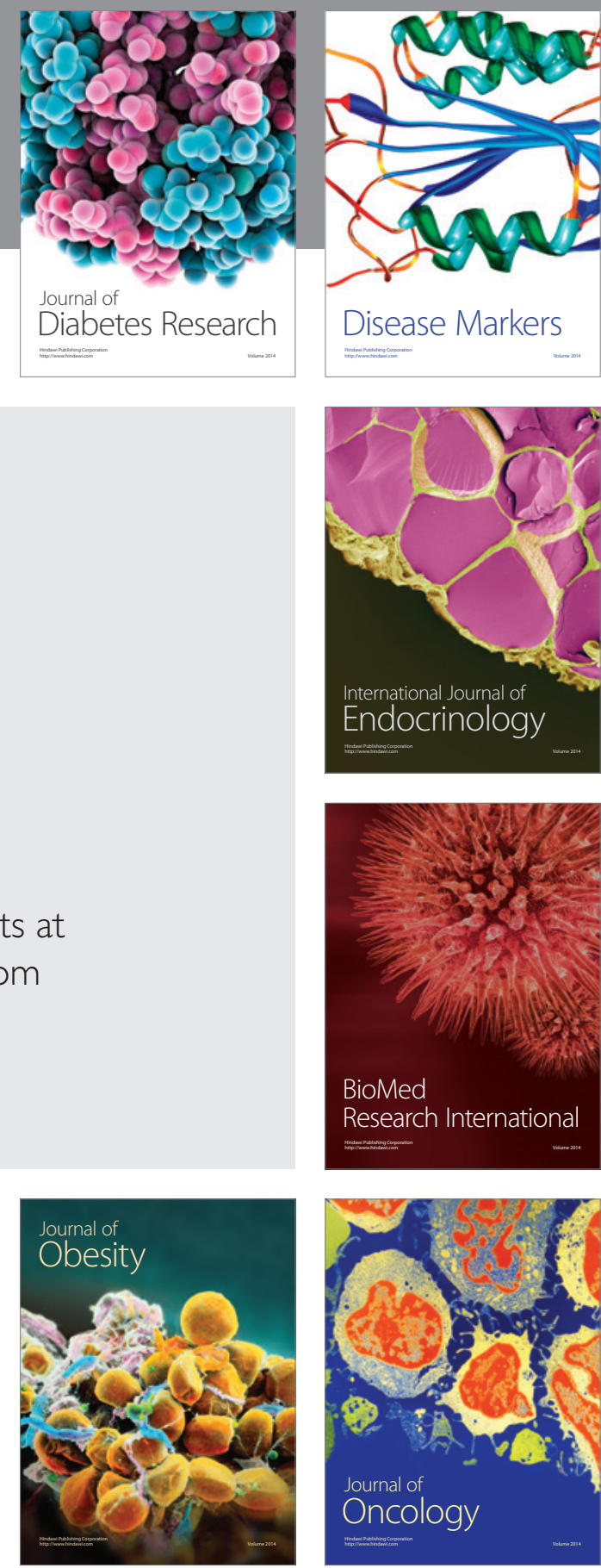

Disease Markers
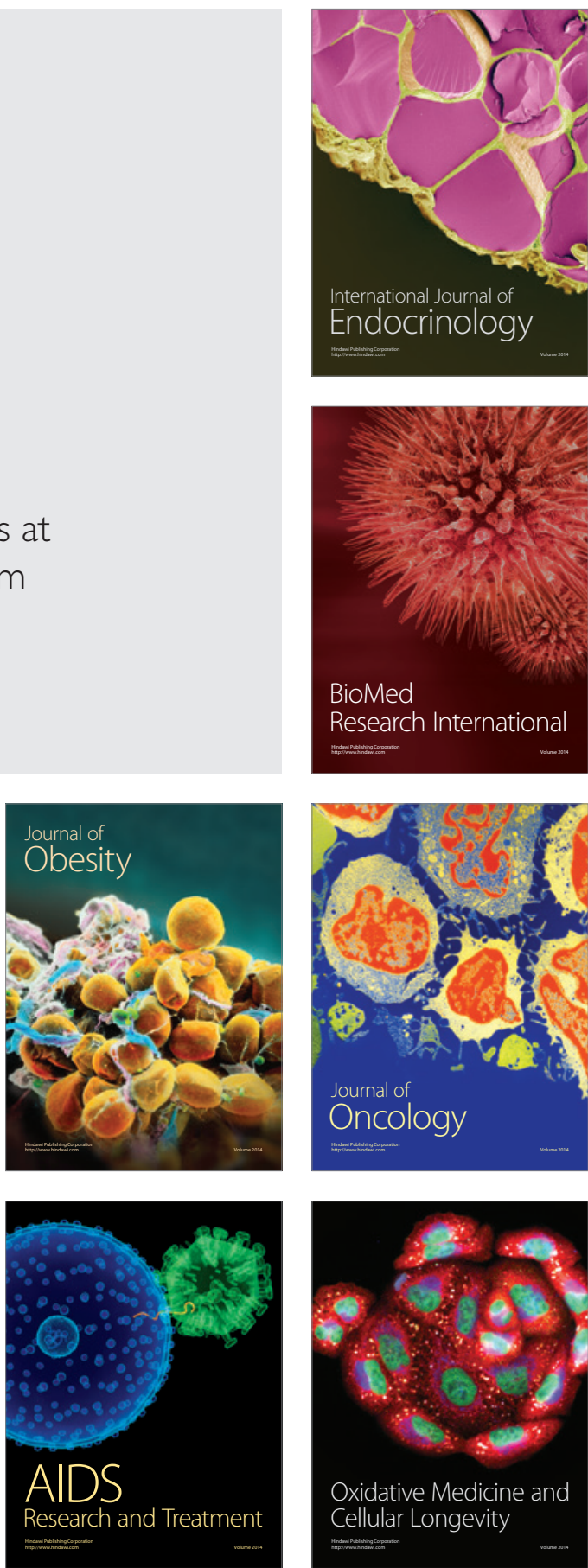